\title{
JUDICIAL DIPLOMACY: INTERNATIONAL COURTS AND LEGITIMATION
}

\author{
Theresa Squatrito \\ Forthcoming in Review of International Studies
}

\begin{abstract}
:
Observers of international courts (ICs) note that several ICs carry out a broad range of nonjudicial activities, ranging from legal training workshops, public seminars and visits with public officials. Despite the growing prominence of these activities, they have received little attention by scholars. Seeking to fill this gap, this article examines these activities as a form of "judicial diplomacy," asking how and why ICs employ judicial diplomacy. The paper argues that ICs use judicial diplomacy as a means of legitimation. They seek to boost institutional legitimacy by targeting the public and communicating normreferential narratives about their processes and performances. This argument bears out in case studies on the judicial diplomacy of the African Court of Human and Peoples' Rights and the Caribbean Court of Justice. Both courts are shown to have judicial diplomacy that is publicoriented and people-centred. This argument has important implications for literature on international courts and the legitimacy of international institutions.
\end{abstract}

Keywords: international court, legitimacy, international institutions, diplomacy

Biography: Theresa Squatrito is an Assistant Professor of International Relations at the London School of Economics and Political Sciences.

Institutional Address: London School of Economics, Department of International Relations, Houghton Street, London WC2A 2AE, United Kingdom

Email: t.j.squatrito@1se.ac.uk

Acknowledgements: I would like to thank Daniel Naurin, Olof Larsson, Michal Parízek, David Kosar, Julian Dederke, Arthur Dyevre, Mathias Koenig-Archibugi, McKenzie Ratner, and participants at the LSE Department of IR's workshop on International Institutions, Law and Ethics for comments on earlier versions of this paper. I also thank the anonymous reviewers for their thoughtful suggestions. 


\section{Introduction}

In December 2017, a delegation from the African Court of Human and Peoples' Rights (ACtHPR) travelled to Cape Verde for a three-day 'sensitisation mission'. The Court's judges and administrators met with Cape Verde's President and Prime Minister, leaders of the National Assembly and Constitutional Court, and other top officials. During this visit, the ACtHRP also hosted a public seminar for stakeholders, such as nongovernmental organizations (NGOs) and local lawyers. ${ }^{1}$ Between 2010 and 2017, the Court carried out twenty-six such missions to member states of the African Union (AU). ${ }^{2}$ The Court continues this practice today. As international courts (ICs) have proliferated since the 1990s, these and other forms of judicial diplomacy have become commonplace for many international courts (ICs). ${ }^{3}$ For example, the International Criminal Court (ICC) in 2015 was budgeted approximately Euros 3.5 million for 'outreach'.

Judicial diplomacy is puzzling for several reasons. First, judges undoubtedly interact with other legal professionals as part of their ordinary professional lives, as they have longterm interests to maintain active engagement with academia or professional associations. However, it is not obvious why a court itself would organize these interactions or how they serve a court's interests. Second, these activities are resource intensive. By conducting judicial diplomacy, ICs may need to channel relatively scarce monetary and human resources away from its core functions. Third, judicial diplomacy risks politicizing the institution and makes judges seem like politicians. When a reputation for independence and impartiality, or

\footnotetext{
${ }^{1}$ ACtHPR, 'Press Release: African Court Successfully Concludes Three Day Sensitization Mission to Cape Verde', 18 December 2017, available at: \{www.african-court.org/en/index.php/news/press-releases/item/213african-court-successfully-concludes-three-day-sensitisation-mission-to-cape-verde \} accessed 23 March 2018. ${ }^{2}$ Ibid.

${ }^{3}$ Victor Peskin, 'Courting Rwanda: The Promises and Pitfalls of the ICTR Outreach Programme', Journal of International Criminal Justice, 3:4 (2005), pp. 950-961; Janine Natalya Clark, 'International War Crimes Tribunals and the Challenge of Outreach', International Criminal Law Review, 9:1 (2009), pp. 99-116.

${ }^{4}$ ICC, 'Approved Budget for 2015', 24 March 2015, available at: \{www.icccpi.int/iccdocs/other/ICC_Approved_Budget_2015.pdf\} access 23 March 2018.
} 
being above the fray of politics, is paramount, visits with current heads of state, national parliamentarians or special interest groups may feed opponents' narratives of judicial bias.

Why then do ICs employ judicial diplomacy? Extant literature suggests that judicial diplomacy reflects ICs efforts to mobilize constituencies or to socialize actors to adopt international norms. According to these accounts, judicial diplomacy targets public officials, legal communities, and civil society while emphasizing procedural and substantive legal provisions. However, judicial diplomacy often targets the public and communicates valueladen narratives about the courts themselves. To explain these aspects of judicial diplomacy, I consider the role of legitimation. I argue that ICs develop and carry out judicial diplomacy to build their legitimacy, especially when the diplomacy targets the public and presents normreferential narratives of their processes and outcomes. Evidence from the ACtHPR and the Caribbean Court of Justice (CCJ) lend support to this argument.

This article contributes to literature on international courts, developing the concept of judicial diplomacy to capture a wide array of non-judicial activities conducted by ICs. Defined as the processes by which international courts represent and claim their authority in their interfacing with external actors, judicial diplomacy casts nonjudicial activities as strategic political behaviours that support a court's judicial roles. Viewed as diplomacy, nonjudicial activities can be clearly recognized as part and parcel to the performance and authority of international courts. ${ }^{5}$

This article also contributes to research on the legitimation of international institutions, which has so far paid minimal attention to international courts. I explain how legitimation applies to international courts and show that legitimation is not exclusively the

\footnotetext{
${ }^{5}$ Karen Alter, Laurence Helfer and Mikael Rask Madsen (eds), International Court Authority (Oxford: Oxford University Press, 2018); Theresa Squatrito, Oran Young, Andreas Follesdal and Geir Ulfstein (eds), The Performance of International Courts and Tribunals (Cambridge: Cambridge University Press, 2018).
} 
result of crisis, scandal and political pressure. ${ }^{6}$ The courts studied here are relatively new institutions, revealing that legitimation can also be part of the normal 'growing pains' for today's international institutions. Lacking a history upon which to draw legitimacy, new institutions are likely to develop strategies of legitimation. Moreover, this article brings to light important synergies between legitimation and diplomacy, offering a potential avenue for future research on legitimation and international institutions.

The article proceeds in five sections. First, it develops the concept of judicial diplomacy. Second, it builds on previous research to identify three theoretical accounts for how and why ICs use judicial diplomacy. Turning to the empirical analysis, the third section describes the research design and the fourth provides the case studies. Finally, the article summarizes the findings and discusses their implications.

\section{What is Judicial Diplomacy?}

As Sending, Pouliot and Neumann explain, 'diplomacy may be defined, in the broadest possible terms, as a claim to represent a given polity to the outside world. Pitched at this level of abstraction, the concept reduces to three key dimensions: first, diplomacy is a process (of claiming authority and jurisdiction); second, it is relational (it operates at the interface between one's polity and that of others); and third, it is political (involving both representation and governing)'. ' Other scholars highlight how diplomacy concerns the

\footnotetext{
${ }^{6}$ Klaus Dingwerth, Antonia Witt, Ina Lehmann, Ellen Reichel and Tobias Weise (eds), International Organizations under Pressure: Legitimating Global Governance in Challenging Times (Oxford: Oxford University Press, 2019); Matthias Ecker-Ehrhardt, 'Self-legitimation in the Face of Politicization: Why International Organizations Centralized Public Communication', Review of International Organizations, 13:4 (2018), pp. 519-546.

${ }^{7}$ Ole Jacob Sending, Vincent Pouliot and Iver Neumann, 'Introduction', in Iver Neumann, Ole Jacob Sending and Vincent Pouliot (eds.) Diplomacy and the Making of World Politics (Cambridge: Cambridge University Press, 2015), p. 5.
} 
representation of an entity ${ }^{8}$ and the structuring and 'conduct of relationships'. ${ }^{9}$ Diplomacy thus entails the claiming of authority, representation of an entity, and is relational (or involves interfacing with external actors).

While diplomacy traditionally concerns inter-state relations and the representation of the state, it 'today takes place among multiple sites of authority, power, and influence'. ${ }^{10}$ Consequently, scholars now speak of 'paradiplomacy', or the diplomatic activity of substate or regional entities, ${ }^{11}$ NGO diplomacy, ${ }^{12}$ diplomacy of international organizations, ${ }^{13}$ and diplomacy of supranational parliaments. ${ }^{14}$ Diplomacy has also been used to describe practices of the $\mathrm{ICC}^{15}$ and the Court of Justice of the European Union (CJEU). ${ }^{16}$

Diplomacy entails a range of practices or activities, 'from negotiation, communication, consular, representation, and reporting to observation, merchandise trade and services promotion, cultural exchange, and public relations'. ${ }^{17}$ This is important because diplomacy often brings images of negotiations and face-to-face dialogue between top state officials, yet it often entails modes of communication, representation and promotion, public relations and more. ${ }^{18}$

\footnotetext{
${ }^{8}$ Paul Sharp, 'For Diplomacy: Representation and the Study of International Relations', International Studies Review, 1:1 (1999), pp. 33-57.

${ }^{9}$ Andrew Cooper, Jorge Heine and Ramesh Thakur, 'Introduction: The Challenges of 21st-Century Diplomacy', in Andrew Cooper, Jorge Heine and Ramesh Thakur (eds.) The Oxford Handbook of Modern Diplomacy

(Oxford: Oxford University Press, 2013), pp. 1-31; see also Christer Jönsson and Martin Hall, 'Communication: An Essential Aspect of Diplomacy', International Studies Perspectives, 4:2 (2003), pp. 195-210.

${ }^{10}$ Cooper et al., 'Introduction', p. 2.

${ }^{11}$ Manuel Duran, Mediterranean Paradiplomacies: The Dynamics of Diplomatic Reterritorialization (Leiden: Brill Nijhoff, 2015).

${ }^{12}$ Michele Betsill and Elisabeth Corell, NGO Diplomacy: The Influence of Nongovernmental Organizations in International Environmental Negotiations (Cambridge, MA: MIT Press, 2008).

${ }^{13}$ Margaret Karns and Karen Mingst, 'International Organizations and Diplomacy', in Andrew Cooper, Jorge Heine and Ramesh Thakur (eds.) The Oxford Handbook of Modern Diplomacy (Oxford: Oxford University Press, 2013), pp. 142-159.

${ }^{14}$ Stelios Stavridis and Davor Jančić, Parliamentary Diplomacy in European and Global Governance (Leiden: Brill Nijhoff, 2017).

${ }^{15}$ Benjamin Schiff, 'Diplomacy and the International Criminal Court', in Andrew Cooper, Jorge Heine and Ramesh Thakur (eds.) The Oxford Handbook of Modern Diplomacy (Oxford: Oxford University Press, 2013), pp. 745-762.

${ }^{16}$ Allan Tatham, 'Off the Bench but Not off Duty: The Judicial Diplomacy of the Court of Justice', European Foreign Affairs Review, 22:3 (2017), pp. 303-322.

${ }^{17}$ Cooper et al., 'Introduction', p. 27.

${ }^{18}$ Sharp, 'For Diplomacy'; Jönsson and Hall, ‘Communication: An Essential Aspect of Diplomacy’.
} 
Building on this understanding of diplomacy, I define judicial diplomacy as a set of practices that are planned and organized by an international court, ${ }^{19}$ whereby it represents itself and claims authority through nonadjudicative interfacing with external actors. ${ }^{20}$ Its central features are four-fold. First, judicial diplomacy is the result of a decision taken by the court itself (not an individual judge). It is planned and organized by the court and conducted on its behalf. Even though individual judges and administrators are the face of judicial diplomacy, it is intended to represent the court (not the judges' own persons). It is not an individual judge deciding by herself to appear at a conference, interact with lawyers, the press, etc.

Second, judicial diplomacy reflects a court's effort to interface and build relationships with external actors. These external actors can be diverse and include public and private actors (e.g., civil society) as well as legal actors (lawyers, legal academics, law students, law societies, etc.) and nonlegal actors. Third, judicial diplomacy is pluralistic: it encompasses a variety of practices and activities ranging from dialogue with government officials, representation at international meetings to public communication. Fourth, it is separate from the process of adjudication or legal interpretation. For example, ICs sometimes conduct factfinding missions when reviewing a dispute. While these transpire outside the courtroom, they are not diplomacy because they are directly part of adjudication.

To summarize, judicial diplomacy captures many, but not all, activities that courts conduct off-the-bench. When part of adjudication, when organized and conducted on behalf

\footnotetext{
${ }^{19}$ ICs are permanent, operational international judicial bodies that issues binding rulings based on international law in disputes where at least one party is a state or international organization; see Cesare Romano, 'A Taxonomy of International Rule of Law Institutions', Journal of International Dispute Settlement, 2:1 (2011), pp. 261-262.

${ }^{20}$ This definition contrasts with 'legal diplomacy' as described by Madsen, which refers to the interplay of law and politics in foreign policy and judicial decision-making; Mikael Rask Madsen, 'Legal Diplomacy' - Law, Politics and the Genesis of Postwar European Human Rights,' in Stefan-Ludwig (ed.) Human Rights in the Twentieth Century (Cambridge: Cambridge University Press, 2010), pp. 62-82).
} 
of individual judges or when not relational, these activities do not meet the criteria of judicial diplomacy.

Judicial diplomacy is widespread. Several international criminal tribunals demonstrate judicial diplomacy. The International Criminal Tribunal for the former Yugoslavia (ICTY) began a program in 1999 to communicate information about the Court and its work to affected populations. ${ }^{21}$ It established an outreach unit, which began 'organizing visits to the ICTY for students, political advisors, officials and military officers; media work; distributing Tribunal publications; delivering presentations at roundtables, conferences and seminars on the Tribunal's work and specific cases; creating a 'Voice of the Victims' section on the Tribunal's new website; providing training for judges, prosecutors and journalists; and engaging with youth organizations such as the Youth Initiative in Belgrade' ${ }^{22}$ Similar efforts have been adopted by the ICC, the Special Court for Sierra Leone and International Criminal Tribunal for Rwanda. ${ }^{23}$ Similarly, the European Court of Human Rights (ECtHR) and the Court of Justice of the European Union (CJEU) employ judicial diplomacy through nonjudicial activities. The ECtHR's 2016 'Bringing the Convention Home' program might be described as judicial diplomacy. This program included trainings for legal professionals and outreach, such as the production of films about the Court for public consumption. ${ }^{24}$ The CJEU, for example, held an annual Meeting with Judges and on other occasions met with presidents or vice-presidents of national judiciaries in $2016 .{ }^{25}$ In the same year, the CJEU gave presentations to 675 groups and welcomed legal trainees to the Court. ${ }^{26}$ It also conducts

\footnotetext{
${ }^{21}$ Clark, 'International War Crimes Tribunals and the Challenge of Outreach'.

${ }^{22}$ Ibid., p. 101-102.

${ }^{23}$ Ibid. (for ICC and Special Court for Sierra Leone); Peskin, 'Courting Rwanda' (for Rwandan tribunal).

${ }^{24}$ ECtHR, '2016 Annual Report of the ECtHR.' (2016), available at: \{www.echr.coe.int/Documents/Annual_report_2016_ENG.pdf\}, accessed 23 March 2018, p. 169-177.

${ }^{25}$ CJEU, 'Annual Report 2016: Year in Review', (2016), available at: \{https://curia.europa.eu/jcms/upload/docs/application/pdf/2017-04/ragp-2016_final_en_web.pdf\}, accessed 23 March 2018, p. 35.

${ }^{26}$ Ibid.
} 
official visits and exchanges with state officials and communicates with citizens via traditional and social media. ${ }^{27}$

Scholars have previously noted the nonjudicial activities of international and domestic courts. Yet, in leveraging the concept of diplomacy to frame these activities, we can approach them as strategic political behaviours which support a court's adjudicative functions. Viewed as diplomacy, these activities are the result of purposive decisions taken by a court to target particular audiences with certain content, all of which raises important questions. Namely, why do ICs decide to employ judicial diplomacy? Who are the target audiences and what is its primary content?

\section{Explaining Judicial Diplomacy}

Leading perspectives on international law and courts offers two accounts for how and why ICs exercise judicial diplomacy. The first suggests that ICs employ judicial diplomacy to mobilize compliance constituencies, while the second suggests that judicial diplomacy is used to socialize actors to adopt legal norms. In this section, I describe these accounts and identify their observable implications.

\section{Constituency Mobilization}

By one account, ICs conduct judicial diplomacy to mobilize compliance constituencies. This logic stems from the rationalist perspective that states comply with international law when compliance aligns with their rational interest. ${ }^{28}$ Pro-compliance constituencies are often essential to compliance due to their capacity to incentivize states to

\footnotetext{
${ }^{27}$ Ibid., pg. 36.

${ }^{28}$ Louis Henkin, How Nations Behave: Law and Foreign Policy (New York: Columbia University Press, 1979).
} 
comply. Compliance constituencies, such as the private sector, civil society and substate actors, incentivize compliance by mobilizing through litigation, lobbying, and electoral accountability. ${ }^{29}$ For example, the CJEU mobilized compliance constituencies by creating opportunities for individual litigants, lawyers and lower courts to use the Court and EU law, which contributes to the Court's successes. ${ }^{30}$

Previous research largely assumes that ICs mobilize compliance constituencies through adjudication, by developing legal doctrines and jurisprudence that empowers the private sector, civil society, and substate actors. ${ }^{31}$ However, judicial diplomacy is another possible means by which international courts can mobilize compliance constituencies. For example, the CJEU courted national judges 'through seminars, dinners, regular invitations to Luxembourg, and visits around the community. ${ }^{32}$

When judicial diplomacy is used to mobilize compliance constituencies, we would expect it to have a combination of two characteristics, one related to its target audiences and the other to its primary content. First, judicial diplomacy will target potential compliance constituencies, like substate (e.g., lower courts) and nonstate actors (e.g., lawyers, the private sector, civil society), especially when these actors have direct access to the court. While these are the general expectations, the targets of judicial diplomacy will be tailor-made for each IC depending on who has the capacity to serve as a compliance constituency. For example, if national courts can make referrals to an IC, we would expect national judges to be among the target audiences. Second, while targeting compliance constituencies, judicial diplomacy will

\footnotetext{
${ }^{29}$ Xinyuan Dai, 'Why Comply? The Domestic Constituency Mechanisms', International Organization, 59:2 (2005), pp. 363-398; Beth Simmons, Mobilizing for Human Rights: International Law in Domestic Politics (New York, NY: Cambridge University Press, 2009); Karen Alter, The New Terrain of International Law: Courts, Politics, Rights (Princeton: Princeton University Press, 2014).

${ }^{30}$ Anne-Marie Burley and Walter Mattli, 'Europe before the Court: A Political Theory of Legal Integration', International Organization, 47:1 (1993), pp. 41-76; Walter Mattli and Anne-Marie Slaughter, 'Revisiting the European Court of Justice', International Organization, 52:1 (1998), pp. 177-209; Karen Alter, Establishing the Supremacy of European Law: The Making of an International Rule of Law in Europe (Oxford; New York: Oxford University Press, 2001).

${ }^{31}$ E.g., Alter, Establishing the Supremacy of European Law.

${ }^{32}$ Burley and Mattli, 'Europe before the Court', p. 62.
} 
deliver mostly informational content, detailing how potential compliance constituencies can utilize the IC or how the law advances their interests. In other words, judicial diplomacy will disseminate information about the procedural aspects of the law (e.g., how to access the court) and the substantive provisions (e.g., legal doctrines, jurisprudence) that are relevant to compliance constituencies.

\section{Norm Entrepreneurship and Socialization}

A second account maintains that ICs use judicial diplomacy to socialize actors to adopt legal norms. This account builds on constructivism and rests on the logic that international law depends on processes of socialization, whereby beliefs about appropriateness diffuse through 'norm entrepreneurship'. Socialization leads actors to internalize and accept norms, or standards of appropriate behaviour, as they are persuaded of the norms' validity. ${ }^{33}$ Actors may alternatively adopt pro-norm behaviour because of social awards or punishments. ${ }^{34}$

Like NGOs and advocacy groups, IOs can be 'teachers of norms', 35 or 'act as agents of socialization by pressuring targeted actors to adopt new policies and laws' ${ }^{36}$ For instance, IOs socialize actors through the use of shaming. ${ }^{37}$ ICs are also able to socialize, and they are

\footnotetext{
${ }^{33}$ Martha Finnemore and Kathryn Sikkink, 'International Norm Dynamics and Political Change', International Organization, 52:4 (1998), pp. 887-917.

${ }^{34}$ Alastair Iain Johnston, 'Treating International Institutions as Social Environments', International Studies Quarterly, 45:4 (2001), pp. 487-515.;

${ }^{35}$ Martha Finnemore, 'International Organizations as Teachers of Norms: The United Nations Educational, Scientific, and Cutural Organization and Science Policy', International Organization, 47:4 (1993), pp. 565-597.

${ }^{36}$ Finnemore and Sikkink, 'International Norm Dynamics and Political Change', p. 902.

37 Theresa Squatrito, Magnus Lundgren and Thomas Sommerer, 'Shaming by International Organizations: Mapping Condemnatory Speech Acts across 27 International Organizations, 1980-2015', Cooperation and Conflict 54:3 (2019), pp. 356-77.
} 
well-suited to be agents of socialization for a few reasons. First, legal processes facilitate norm socialization. ${ }^{38}$ Second, ICs have moral and expert authority, ${ }^{39}$ which improves their persuasiveness. Third, international judges and IC staff are often highly committed to the legal norms of their courts.

While courts socialize others primarily through adjudication and their decisions (e.g., making validity claims in legal argumentation), they can also use nonjudicial activities. ${ }^{40}$ Nonjudicial channels could be especially useful for these purposes because ICs can encourage adherence proactively. Otherwise, ICs are primarily restricted to socializing actors after norms are violated. Thus, judicial diplomacy can reflect an IC's efforts to promote norms.

If judicial diplomacy were used to socialize actors, we would expect public officials to be a crucial target, as they hold the power to bring law and policy into conformity with norms. ${ }^{41}$ Also, the process of socialization 'is not necessarily or entirely in the realm of reason, though facts and information may be marshaled to support claims. Affect, empathy, and principled or moral beliefs may also be deeply involved' ${ }^{42}$ For this reason, we would expect the content of judicial diplomacy to express validity claims and persuasive arguments about the substantive provisions of law while targeting public officials. For example, it may entail shaming of nonconforming state behaviour or praising of their norm conformity.

\section{Judicial Diplomacy as Legitimation}

\footnotetext{
${ }^{38}$ Ryan Goodman and Derek Jinks, Socializing States Promoting Human Rights through International Law (Oxford: Oxford University Press, 2013).

${ }^{39}$ Karen Alter, 'Agents or Trustees? International Courts in their Political Context', European Journal of International Relations, 14:1 (2008), pp. 33-63.

${ }^{40}$ Nicole De Silva, 'International Courts' Socialization Strategies for Actual and Perceived Performance', in Theresa Squatrito, Oran Young, Andreas Follesdal and Geir Ulfstein (eds.) The Performance of International Courts and Tribunals (Cambridge: Cambridge University Press, 2018), pp. 288-323.

${ }^{41}$ Nonstate actors may be a secondary target of judicial diplomacy from this perspective, as these actors may have leverage over public officials.

${ }^{42}$ Martha Finnemore and Kathryn Sikkink, 'International Norm Dynamics and Political Change', p. 900.
} 
Mobilization of compliance constituencies and norm socialization suggest judicial diplomacy will target public officials, sub-state and nonstate actors and communicate information and persuasive arguments about the procedure and substance of the law. Nonetheless, these explanations are ill equipped to explain why, for instance, judicial diplomacy is often oriented toward the public and embedded with value-laden narratives about the courts themselves. Why do courts aim to communicate with the mass public while proclaiming their respect for procedural rules, fairness and impartiality, or community values and their mandates? The following discussion elaborates on my account, which suggests that legitimacy provides the key to understanding these aspects of judicial diplomacy.

Legitimacy refers to the 'beliefs within a given constituency or other relevant audience that a political institution's exercise of authority is appropriate' ${ }^{43}$ It is a subjective and intersubjective quality of an institution, not an objective quality about the moral justifiability of an institution or its 'right to rule' — even though an actor's beliefs about an institution may be informed by its objective quality. ${ }^{44}$

The impact of legitimacy on behaviour is different from the logic of appropriateness. Most important, the logic of appropriateness assumes that actors adhere to the precepts of a norm for content-dependent reasons. One conforms to a norm because it espouses a value or prescription that he or she believes is appropriate. Legitimacy implies that adherence to a rule or norm follows from the appropriateness of the institution that produces it, not from the content of the norm. Stated differently, legitimacy generates moral, content-independent reasons to adhere to any one norm or rule. ${ }^{45}$

\footnotetext{
${ }^{43}$ Jonas Tallberg and Michael Zürn, 'The Legitimacy and Legitimation of International Organizations: Introduction and Framework', Review of International Organizations, 14:4 (2019), p. 585; see also Dane Imerman, 'Contested Legitimacy and Institutional Change: Unpacking the Dynamics of Institutional Legitimacy', International Studies Review, 20:1 (2018), pp. 74-100.

${ }^{44}$ I use the term 'institution' to refer to formal institutions, or organizations, including international courts.

${ }^{45}$ Allen Buchanan and Robert Keohane, 'The Legitimacy of Global Governance Institutions', Ethics and International Affairs, 20:4 (2006), pp. 405-437.
} 
Legitimacy is crucial for international institutions, including courts. It is a source of power that facilitates compliance, acting as both a normative motivation and rational constraint on the behaviour of states. ${ }^{46}$ Legitimacy is especially important for ICs, which lack coercive capacity. While national courts are backed by the coercive power of the state, ICs do not benefit from the same coercive support. States are rarely willing to back an IC to coerce one another to comply. At the same time, states' rational self-interests cannot fully account for (non)compliance with ICs. States may defy an IC, despite being in their interests to comply, and states sometimes comply even though there are few interests to do so. These instances highlight how legitimacy provides power ${ }^{47}$ and 'compliance pull', ${ }^{48}$ and why some scholars define legitimacy as beliefs that an institution 'ought to be obeyed' ${ }^{49}$

Legitimacy is also important because it can influence an institution's performance, such as its usage and relevance for problem solving. ${ }^{50}$ States and individuals are unlikely to turn to a court for recourse if it is not viewed as an appropriate authority. Moreover, institutions that exercises significant authority but lack legitimacy can become highly politicized, ${ }^{51}$ leading to resistance and contestation and threats of exit, voice or creation of alternative institutions. ${ }^{52}$

Institutional legitimacy is variable and 'sensitive to existing social and material conditions, which are constantly evolving', ${ }^{53}$ In other words, an institution that was once

\footnotetext{
${ }^{46}$ Imerman, 'Contested Legitimacy and Institutional Change'; Ian Hurd, After Anarchy: Legitimacy and Power in the United Nations Security Council (Princeton: Princeton University Press, 2007).

${ }^{47}$ Ian Hurd, 'Legitimacy and Authority in International Politics', International Organization, 53:2 (1999), pp. 379-408. Self-interest and legitimacy as sources of power can be mutually reinforcing, and they are likely to both contribute to why actors comply with international law and courts. Nevertheless, the underpinnings of how ICs understand their strategic environment, and their own sources of power, have different behavioral implications.

48 Thomas Franck, The Power of Legitimacy among Nations (Oxford: Oxford University Press, 1990).

${ }^{49}$ Ian Hurd, After Anarchy, p. 30.

50 Tallberg and Zürn, 'The Legitimacy and Legitimation of International Organizations'.

${ }^{51}$ Michael Zürn, Martin Binder and Matthias Ecker-Ehrhardt, 'International Authority and its Politicization', International Theory, 4:1 (2012), pp. 69-106.

52 Julia Morse and Robert Keohane, 'Contested multilateralism', Review of International Organizations, 9:4 (2014), pp. 385-412.

${ }^{53}$ Imerman, 'Contested Legitimacy and Institutional Change', p. 75.
} 
legitimate may no longer be legitimate. Pressures, like a declining relevance to current problems, rising authority, a growing density of international organizations, or increasing demands from civil society, can produce legitimacy losses. ${ }^{54}$ Moreover, the normative yardsticks against which legitimacy beliefs are held can shift with time. ${ }^{55}$

All of these dynamics motivate international institutions to behave instrumentally and develop strategies and institute policies to boost their legitimacy. ${ }^{56}$ These strategieswhereby actors deliberately seek to generate and promote, among relevant audiences, beliefs in the rightfulness of a political institution — are referred to as legitimation. ${ }^{57}$ Legitimation highlights institutions' processes and/or outcomes. ${ }^{58}$ It occurs through various modes, including public communication, ${ }^{59}$ procedural reforms or changes to institutional design, among others. ${ }^{60}$ For example, the UNSC's legitimation strategies included several reforms, ranging from increased reliance on external experts to changes to its committee structure. ${ }^{61}$ The creation of international parliamentary assemblies has also been described as a strategy

\footnotetext{
${ }^{54}$ Klaus Dingwerth, Antonia Witt, Ina Lehmann, Ellen Reichel and Tobias Weise, 'International Organizations under Pressure: Introduction', in International Organizations under Pressure (Oxford: Oxford University Press, 2019), p. 4-5.

55 Dingwerth et al., International Organizations under Pressure.

${ }^{56}$ Imerman, 'Contested Legitimacy and Institutional Change'; Dingwerth et al., International Organizations under Pressure; Dominik Zaum (ed.), Legitimating International Organizations (Oxford: Oxford University Press, 2013); Jens Steffek, 'The Legitimation of International Governance: A Discourse Approach', European Journal of International Relations, 9:2 (2003), pp. 249-275; Ecker-Ehrhardt, 'Self-legitimation in the Face of Politicization'.

57 Tallberg and Zürn, 'The Legitimacy and Legitimation of International Organization'; Dingwerth et al., International Organizations under Pressure.

58 Tallberg and Zürn, 'The Legitimacy and Legitimation of International Organizations'; Lisa Dellmuth, Jan Aart Scholte and Jonas Tallberg, 'Institutional Sources of Legitimacy for International Organisations: Beyond Procedure versus Performance', Review of International Studies, 45:4 (2019), pp. 627-646. Some legitimation literature refers to procedures and performance. I use process and outcomes because broader literature conceives of performance as including of processes and outcomes; see Tamar Gutner and Alex Thompson, 'The Politics of IO Performance: A Framework', Review of International Organizations, 5:3 (2010). 227-248; Squatrito et al. The Performance of International Courts and Tribunals.

${ }^{59}$ Ecker-Ehrhardt, 'Self-legitimation in the Face of Politicization'.

${ }^{60}$ Jennifer Gronau and Henning Schmidtke, 'The Quest for Legitimacy in World Politics - International Institutions' Legitimation Strategies', Review of International Studies, 42:3 (2016), pp. 535-557.

${ }^{61}$ Jennifer Welsh and Dominik Zaum, 'Legitimation and the UN Security Council', in Dominik Zaum (ed.) Legitimating International Organizations (Oxford: Oxford University Press, 2013), pp. 65-87.
} 
of legitimation. ${ }^{62}$ Finally, an institution can direct its legitimation toward external audiences or internal audiences (e.g., personnel). ${ }^{63}$

ICs will be prone to develop strategies of legitimation because they 'cannot rely upon the 'presumption of legitimacy' associated with national institutions' ${ }^{64}$ Also, as their authority and importance to global governance has expanded, ${ }^{65}$ many are confronting significant politicization, contestations, resistance and 'backlash' ${ }^{66}$ The ICC provides an illustrative example: states have threatened and proceeded to withdraw their membership, the AU has begun the process of creating a court with competing jurisdiction, and the US has threatened the ICC's prosecutor for investigating atrocities. ${ }^{67}$ Additionally, many ICs are relatively new, ${ }^{68}$ and therefore do not have historical legacies to provide a reservoir of support. In circumstances such as these, ICs may act instrumentally and turn to judicial diplomacy to boost their legitimacy.

As a means of legitimation, judicial diplomacy has distinct characteristics. We would expect its target audiences to cover a broad spectrum of stakeholders to generate 'diffuse support' ${ }^{69}$ In particular, a distinct target audience of judicial diplomacy for legitimation purposes is the public. Recent scholarship on IO legitimation points to evidence of broad

\footnotetext{
${ }^{62}$ Jofre Rocabert, Frank Schimmelfennig, Loriana Crasnic and Thomas Winzen, 'The Rise of International Parliamentary Institutions: Purpose and Legitimation', Review of International Organizations, 14:4 (2019), pp. 607-631; Berthold Rittberger, Building Europe's Parliament: Democratic Representation beyond the Nationstate (Oxford: Oxford University Press, 2005).

${ }^{63}$ I focus on externally directed legitimation, even though it may simultaneously affect internal audiences' beliefs. While previous literature refers to externally directed legitimation as 'self-legitimation', I adopt von Billerbeck's approach which differentiates between externally and internally directed legitimation, using 'selflegitimation' to refer to the latter; Sarah von Billerbeck, (2020). 'No Action without Talk? UN Peacekeeping, Discourse, and Institutional Self-legitimation', Review of International Studies, online first (2020), pp. 1-18.

${ }^{64}$ James Gibson and Gregory Caldeira, 'The Legitimacy of Transnational Legal Institutions: Compliance, Support, and the European Court of Justice', American Journal of Political Science, 39:2( 1995), pp. 464. ${ }^{65}$ Alter, The New Terrain of International Law.

${ }^{66}$ Mikael Rask Madsen, Pola Cebulak and Micha Wiebusch, 'Backlash against International Courts: Explaining the Forms and Patterns of Resistance to International Courts', International Journal of Law in Context, 14:2 (2018), pp. 197-220.

${ }^{67}$ Kurt Mills and Alan Bloomfield, 'African Resistance to the International Criminal Court: Halting the Advance of the Anti-impunity Norm', Review of International Studies, 44:1 (2018), pp. 101-124.

${ }^{68}$ Alter, The New Terrain of International Law.

${ }^{69}$ David Easton, A Systems Analysis of Political Life (New York: John Wiley \& Sons, 1965).
} 
efforts to shape public views. ${ }^{70}$ Ecker-Erhardt finds the ICC, the Council of Europe and the Organization of American States have the highest degree of public communication (which he argues is associated with legitimation). ${ }^{71}$ It is probably no coincidence then that these IOs have among the most salient ICs (the ICC's judicial chambers, ECtHR and Inter-American Court of Human Rights, respectively) at their core. Also, we know that domestic courts rely on public support. ${ }^{72}$

The same is likely to be the case for ICs, even though there is no direct electoral connection between them and the public. Drawing on the understanding that international processes interact with domestic politics, ${ }^{73}$ we can see how public support matters to ICs. First, public support has bearing on state compliance with international judicial decisions. ${ }^{74}$ If an international court is viewed favourably by domestic constituencies, state policymakers may find it political costly to defy that court. ${ }^{75}$ Conversely, when an IC enjoys minimal public support, states have few domestic incentives to comply. Second, favourable public opinion can insulate an IC from political attack. ${ }^{76}$ Third, diffuse support may affect judicial decision-making. ${ }^{77}$ Fourth, recent research suggests that the public is increasingly searching

\footnotetext{
${ }^{70}$ Tallberg and Zürn, 'The Legitimacy and Legitimation of International Organizations'; Ecker-Ehrhardt, 'Selflegitimation in the Face of Politicization'.

${ }^{71}$ Ecker-Ehrhardt, 'Self-legitimation in the Face of Politicization', p. 535.

72 James Gibson, Gregory Caldeira and Vanessa Baird, 'On the Legitimacy of National High Courts', American Political Science Review, 92: 2 (1998), pp. 343-358; Georg Vanberg, The Politics of Constitutional Review in Germany (Cambridge: Cambridge University Press, 2005).

${ }^{73}$ Robert Putnam, 'Diplomacy and Domestic Politics: The Logic of Two-Level Games', International Organization 42: 3 (1988), p. 427-60.

${ }^{74}$ James Gibson and Gregory Caldeira, 'The Legitimacy of Transnational Legal Institutions: Compliance, Support, and the European Court of Justice', American Journal of Political Science, 39:2 (1995), pp. 459-89. 75 Xinyuan Dai, 'Why Comply?'; Beth Simmons, Mobilizing for Human Rights.

${ }^{76}$ Daniel Kelemen, 'The Political Foundations of Judicial Independence in the European Union', Journal of European Public Policy, 19:1 (2012), pp. 43-58.; Tom Ginsburg, 'Political Constraints on International Courts', in Cesare Romano, Karen Alter and Yuval Shany (eds.) The Oxford Handbook of International Adjudication (Oxford: Oxford University Press, 2013), pp. 494;.

${ }^{77}$ Recent research on the CJEU shows that the Court's decisions are influenced by policy-specific public opinion. Michael Blauberger, Anita Heindlmaier, Dion Kramer, Dorte Sindbjerg Martinsen, Jessica Sampson Thierry, Angelika Schenk \& Benjamin Werner, 'ECJ Judges Read the Morning Papers. Explaining the Turnaround of European Citizenship Jurisprudence', Journal of European Public Policy, $25: 10$ (2018), pp. 1422-1441; Michael F. Harsch and Vladislav Maksimov, 'International Courts and Public Opinion: Explaining the CJEU's Role in Protecting Terror Suspects' Rights', Journal of Common Market Studies 57:5 (2019), pp. 1091-110.
} 
out information on international courts, ${ }^{78}$ and outreach by courts can affect the public's opinion of an IC.$^{79}$ Fifth, international judges want the esteem of the public, believing it is instrumental to their work. As one international judge described, courts' 'need to establish their relevance, their integrity, and their effectiveness. To do so, they need to be seen and heard, not just by the legal and diplomatic communities, but also by a broad cross-section of the citizenry' ${ }^{80}$ Given the significance of the public to ICs, we would expect judicial diplomacy to target the public if it were concerned with legitimation.

Legitimation suggests that judicial diplomacy will not only target the public but also interested stakeholders. These stakeholders include public and nonstate actors, as well as legal and nonlegal audiences. ${ }^{81}$ Stakeholders' views, however, are likely to differ. A court may be held in higher esteem with legal professionals than with state officials, for instance. In addition to the public, legitimation will therefore target stakeholders where deficits in support exist.

We would expect the content of judicial diplomacy to go beyond the substantive and procedural provisions of law. Rather, it will portray the 'rightfulness' of the court itself, highlighting value-laden messages about its processes and outcomes. The portrayal of its processes and outcomes will typically be 'norm-referential' ${ }^{82}$ In terms of processes, Dingwerth and his colleagues find that, while variable, the norms referenced often relate to

\footnotetext{
${ }^{78}$ Erik Voeten, 'Public Opinion and the Legitimacy of International Courts', Theoretical Inquiries in Law 14:2 (2013), p. 411-36; Pelc, Krzysztof, 'Googling the WTO: What Search-Engine Data Tell Us About the Political Economy of Institutions', International Organization 67:3 (2013), pp. 629-55.

${ }^{79}$ Geoff Dancy, Yvonne Marie Dutton, Tessa Alleblas and Eamon Aloyo, 'What Determines Perceptions of Bias toward the International Criminal Court? Evidence from Kenya', Journal of Conflict Resolution, OnlineFirst, (2019).

${ }^{80}$ Daniel Terris, Cesare Romano and Leigh Swigart, The International Judge: An Introduction to the Men and Women who Decide the World's Cases (Oxford: Oxford University Press, 2007), p. 170.

${ }^{81}$ Interested stakeholder can overlap closely with compliance constituencies.

${ }^{82}$ Klaus Dingwerth and Antonia Witt, 'Legitimation Contests: A Theoretical Framework', in International Organizations under Pressure (Oxford: Oxford University Press, 2019); Michael Barnett and Martha Finnemore, Rules for the World: International Organizations in Global Politics (Ithaca, NY: Cornell University Press, 2004), pp. 166-167.
} 
adherence to rules and correct procedure. ${ }^{83}$ Similarly, the fairness of procedures can affect an IOs legitimacy. ${ }^{84}$ For an IC, this will translate into messages about adherence to rules and correct procedures, procedural fairness, or impartial and independent adjudication. Judicial diplomacy, for example, will convey the court's respect for the rules of admissibility and the confines of its jurisdiction. Legitimation will also present narratives about outcomes, or 'claim legitimacy on substantive grounds, because they promote values and pursue goals shared by the international community ${ }^{85}$ Along these lines, Dingwerth et al. find that legitimation increasingly focuses on the people or communities represented by the institution. ${ }^{86}$ To this end, an IC might emphasize its commitment to and fulfilment of its founding principles or mandate and its promotion of community values. Thus, we would expect strategic legitimation to reveal itself in judicial diplomacy through norm-referential narratives about the court's processes and outcomes that targets the public and stakeholders where deficits exist.

Table 1. Observable implications by explanation for judicial diplomacy

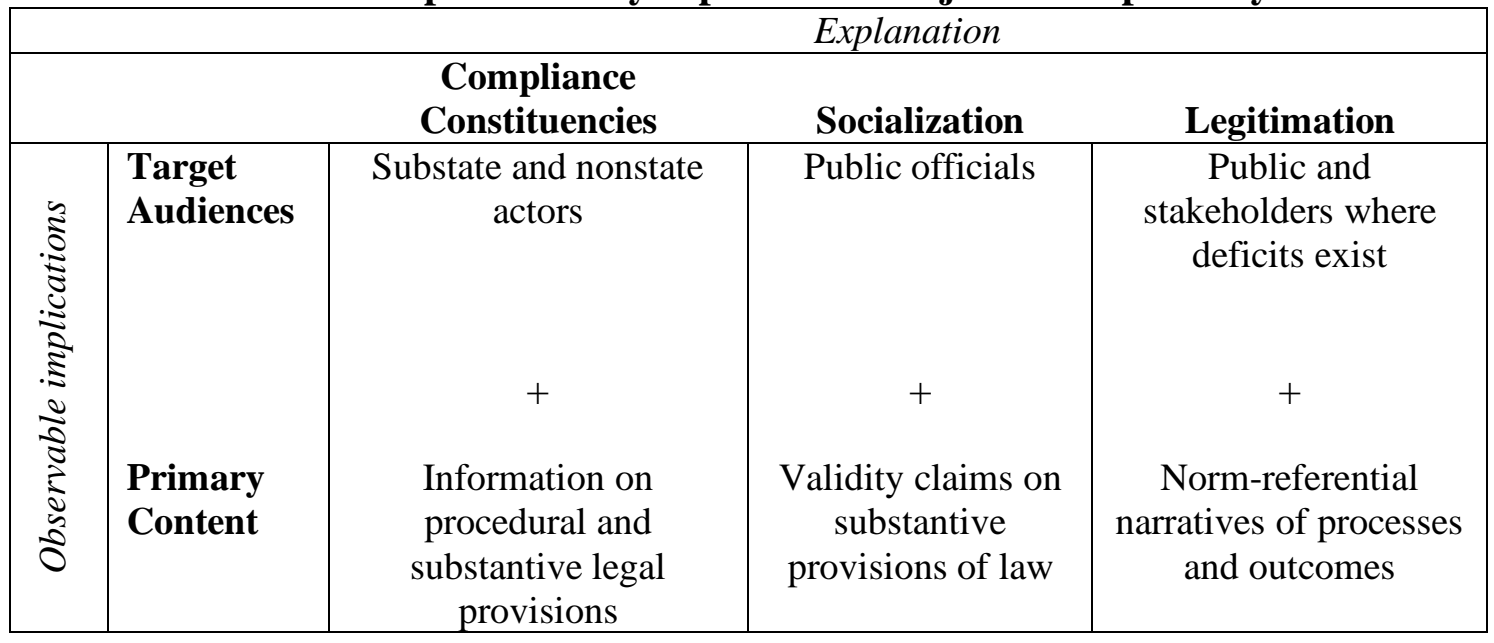

\footnotetext{
${ }^{83}$ Dingwerth et al., International Organizations under Pressure.

${ }^{84}$ Dellmuth et al., 'Institutional Sources of Legitimacy for International Organisations'.

${ }^{85}$ Buchanan and Keohane, 'The Legitimacy of Global Governance Institutions', p. 168.

${ }^{86}$ Dingwerth et al., International Organizations under Pressure.
} 
The previous discussion elaborates on three accounts of judicial diplomacy and theorizes the observable implications for each account (summarize in Table 1). Each account has distinct expectations about the combination of targets and content of judicial diplomacy. These observable implications guide the empirical analysis.

Before proceeding, a few caveats are worth mentioning. First, the theoretical accounts that I have identified need not be competing explanations for how and why ICs conduct judicial diplomacy. ICs can have more than one motivation for conducting diplomacy. Nevertheless, the prominence of one over the other(s) may vary over time or by courts. Second, these explanations are not necessarily exhaustive, although I do expect these to be the most prominent and generalizable motivations. All ICs have concerns for compliance, socialization and legitimacy. This is not the case with other plausible motivations, such as the need to elicit monetary support from donors. For example, the CCJ is financially secure, while the ACtHPR relies on donors. In addition, these logics are well-grounded in previous theoretical perspectives relevant to international law, courts and organizations.

\section{Research Design}

I examine the theoretical argument through qualitative case studies on the African Court of Human and Peoples' Rights and the Caribbean Court of Justice. The selection of these two cases is advantageous for several reasons. First, as relatively new courts, they need to develop compliance constituencies and socialize states to adopt norms. In terms of research design, this selection of cases holds constant these two logics, while probing for the plausibility of legitimation. Also, the infancy of both courts provides insights into how newness shapes legitimation. Second, the courts differ in several aspects of their design, which helps to understand the generalizability of the findings. The CCJ and ACtHPR have different ratione 
materiae (subject-matter) jurisdiction: the CCJ deals with regional integration law while the ACtHPR has jurisdiction over international human rights law. They have different rules on access and admissibility (described later) and funding arrangements. ${ }^{87}$ The processes for selecting judges and the terms of appointments differ. ${ }^{88}$ Also, they are dissimilar in terms of competing jurisdictions. ${ }^{89}$ Third, there is limited research on the ACtHPR and CCJ, allowing this study to shed light on two previously understudied courts.

The case studies rely on qualitative content analysis of four types of data. First, I examine all published annual reports of each court (spanning their lifetime) to identify judicial diplomacy. A focus on annual reports helps to restrict the inclusion of nonjudicial activities to only those that are centrally organized. The reports do not typically document the activities that individual judges pursue for personal reasons. Second, I use speeches and presentations made by representatives of the courts. Only speeches and presentations published on the courts' websites ${ }^{90}$ or social media pages are included, assuming if a court has posted them, it sanctioned these activities and views them as a representation of the court. Third, I rely on each court's press releases, also on the assumption that the activities mentioned in press releases are conducted on behalf of the court. Fourth, I use interviews conducted with judges, registrars and other personnel of the court, as well as regional

\footnotetext{
${ }^{87}$ The CCJ is financially secure. It is funded by an independent trust fund and states do not control its budget. States indirectly control the ACtHRP's funding and budgeting. The ACtHPR has significant economic shortfalls; Theresa Squatrito, 'Resourcing Global Justice: The Resource Management Design of International Courts', Global Policy 8:5 (2017), pp. 62-74.

88 The ACtHPR's judges are nominated and selected by states for six-year, once renewable terms. Judges of the $\mathrm{CCJ}$ apply for open positions and are selected by an independent commission to serve until retirement. See respective protocols cited below.

${ }^{89}$ The CCJ does not have a competing jurisdiction on community law (but it does in its appellate jurisdiction). The ACtHPR's jurisdiction competes with that of the ECOWAS court (for ten states have overlapping membership, but only six allow private access). The ACmHPR has complementary jurisdiction with the ACtHPR.

${ }^{90}$ Some data were received by direct request to the ACtHRP as it was no longer available on its website.
} 
lawyers. ${ }^{91}$ I exclude all activities that are directly related to adjudication. The case studies are constructed by triangulating these data.

\section{Judicial diplomacy and the African Court of Human and Peoples Rights}

The AU established the ACtHPR in 1998 by adoption of the Protocol to the African Charter on Human and People's Rights on the Establishment of the African Court on Human and Peoples' Rights (herein African Court Protocol). To date, thirty states have ratified the African Court Protocol and are therefore subject to the Court's jurisdiction. The ACtHPR became operational in 2006, received its first application in 2008, and issued its first decision in 2009. The ACtHPR interprets and applies the African Charter on Human and Peoples' Rights (herein African Charter), the African Court Protocol, and any other human rights instruments ratified by the concerned states. ${ }^{92}$ Individuals and NGOs with observer status to the African Commission on Human and Peoples' Rights (ACmHPR) can petition the Court against states that have made a declaration accepting private access, according to Article 34(6). ${ }^{93}$ The ACmHPR, African intergovernmental organizations and member states can also refer cases to the Court. $^{94}$

\section{Targets of Judicial Diplomacy}

Judicial diplomacy is a regular part of the ACtHPR's activities. The Court demonstrates concerted efforts to reach several audiences in its judicial diplomacy. One of the ACtHPR's most prominent, repeat exercises of judicial diplomacy are 'sensitization'

\footnotetext{
${ }^{91}$ A total of 30 interviews were conducted in November-December 2015 (ACtHPR) and March - April 2016 (CCJ). I also observed the ACtHPR's moot court competition from November 30 to December 3, 2015.

${ }_{92}$ Protocol to the African Charter on Human and Peoples' Rights on the Establishment of an African Court on Human and People's Rights, OAU Doc. OAU/LEG/MIN/ACTHPR/PROT.1 rev.2 (1997), entered into force January 25, 2004, available at: \{http://au.int/en/treaties/protocol-african-charter-human-and-peoples-rightsestablishment-african-court-human-and \}, accessed 6 December 2016, Art. 3.

${ }^{93}$ Ibid., Art. 5.

${ }^{94}$ Ibid.
} 
visits. Every year since 2010, the ACtHPR has sent a delegation (usually including the Registrar and at least one judge) to visit member states. ${ }^{95}$ Typically, these visits include a meeting with top government officials, such as presidents or prime ministers, attorney generals, or ministers of justice as well as legislative or parliamentary leaders and judges of the national apex court. Sometimes the delegation holds meetings with officials from national human rights institutions, such as an ombudsman or human rights commissioner. According to the Court, the objectives of these meetings include 'encouraging the ratification and the deposit of the Declaration under Article 34(6) of the Protocol of the Court that allows individuals and NGOs direct access to the Court. ${ }^{96}$ The sensitization visits also engage with civil society, especially human rights groups, and the legal community. For example, on several occasions a member of the ACtHPR has delivered a lecture at a law school as part of these visits. Also, the Court hosts a half-day or full-day seminar with civil society. The stated objectives for these activities include: 'sensitizing would-be applicants on how to access the Court and the procedures before the Court'.97

Apart from the sensitization visits, the ACtHPR has organized numerous conferences. For example, in 2013, the Court hosted a Continental Consultative and Sensitization Seminar on the Promotion of the Court for Women Human Rights NGOs in Africa. ${ }^{98}$ Also in 2013, the Court hosted a Continental Seminar on Judicial Dialogue with National Judiciaries. This seminar 'was attended by a total of 74 participants', including 10 national and international judges, representatives from regional institutions (e.g., AU), legal associations, and academics. ${ }^{99}$ This conference is now held on a biennial basis. Another example of a

\footnotetext{
95 Sensitization visits are documented and described in the Court's annual reports, available at: http://www.african-court.org/en/index.php/publications/activity-reports.

96 ACtHPR, 'Press Release: African Court Successfully Concluse Three Day Sensitization Mission to Cape Verde'.

${ }^{97}$ Ibid.

${ }^{98}$ ACtHPR, 'Activity Report of the African Court for the Year 2013', AU Executive Council, Twenty-Fourth Ordinary Session, 21-28 January 2014, EX.CL/825(XXIV), available at: \{www.africancourt.org/en/index.php/publications/activity-reports\}, accessed 23 March 2018, para. 71-73.

99 Ibid., para. 77-80.
} 
conference organized by the Court was the International Symposium celebrating the $10^{\text {th }}$ Anniversary of the Court. ${ }^{100}$ Representatives of the Court also attend and participate in academic, advocacy, and practitioners' conferences. All of these activities are ways in which the Court interacts with public officials, national courts, lawyers, and civil society organizations. ${ }^{101}$

While many of the exercises of judicial diplomacy target actors who are potential compliance constituencies and relevant to socialization, the ACtHPR also recognizes that low acceptance by these audiences is problematic. By its own assessment, the Court identified 'the low level of ratification of the Protocol' and the 'slow rate of deposit of the declaration allowing individuals and NGOs direct access to the Court' among its key challenges. ${ }^{102}$ Approximately half of the AU's member states have not ratified the African Court Protocol to accept the Court's jurisdiction, despite having all ratified the African Charter. Only ten states have accepted individuals' and NGOs' access to the Court. ${ }^{103}$

The Court also targets the public through its judicial diplomacy, which is uniquely expected by a logic of legitimation. The Court has identified a lack of public awareness and acceptance as a challenge. ${ }^{104}$ When developing the Court's 2016-2020 Strategic Plan, the then president of the Court claimed: 'We have to intensify our efforts to increase the visibility of the Court so that more people and stakeholders understand the existence of the Court and hope that in return they will presurize [sic] their States to ratify and or deposit

\footnotetext{
${ }^{100}$ ACtHPR, 'Activity Report of the African Court for the Year 2016', AU Executive Council Thirtieth Ordinary Session, 22-27 January 2017, Ex .CL/999(XXX), available at: \{http://www.africancourt.org/en/index.php/publications/activity-reports\}, accessed 23 March 2018, para. 52.

${ }^{101}$ See annual reports.

102 ACtHPR, 'Activity Report of the African Court for the Year 2016', para. 31.

103 These states are: Benin, Burkina Faso, Cote d'Ivoire, Gambia, Ghana, Malawi, Mali, Rwanda, Tanzania, and Tunisia. Four of these states have withdrawn their article 34(6) declaration. Rwanda withdrew it in February 2016, which came into effect on 28 February 2017. Tanzania gave notice to withdraw in November 2019, Benin in March 2020 and Cote d'Ivoire in April 2020. Withdrawals enter into force after 12 months.

${ }^{104}$ E.g., ACtHPR, 'Activity Report of the African Court for the Year 2016'.
} 
declarations' ${ }^{105}$ The strategic plan went on to identify the lack of public awareness as a 'threat' to the Court and to adopt 'outreach and coordination' as one of four main goals, with an objective of 'build[ing] the Court's reputation and profile as a veritable pillar in the African Human Rights architecture and improve awareness of the Court by engaging stakeholders'. ${ }^{106}$ On an earlier occasion, Judge Akuffo noted: 'there is an overall lack of awareness about the very existence of the Court among Africans across the board, let alone adequate knowledge about who may access the Court, how they may do so and the nature of applications that might be brought before the Court' ${ }^{107}$ Interviewees expressed similar concerns with the ACtHPR's public image. For example, one interviewee explained: 'we are sensitive to the public's perception about the Court, especially the image of the Court'. ${ }^{108}$

The Court also demonstrates that it recognizes its own ability to shape its public image. As one interviewee stated: 'The Court must take care of its own public relations. And so...we've come along to accept that'. ${ }^{109}$ More recently, the current President of the Court, Sylvain Oré, impressed upon the Court's need to address its public image, urging the Court to work on its publicity to counter existing negative impressions made by states and sentiments of public opinion. ${ }^{110}$

To address the Court's image with the public, the ACtHPR decided to employ nonjudicial activities. Judge Akuffo explained in a speech how the Court has sought to

\footnotetext{
105 Augustino Ramadhani, 'Statement at the Opening of the Validation of the African Court's Strategic Plan' 5 March 2016, Arusha, Tanzania.

${ }^{106}$ ACtHPR, ‘2016-2020 Strategic and Implementation Plan' (Arusha, Tanzania, 2016).

${ }^{107}$ Sophia Akuffo, 'Report of the ACtHPR on the Relevant Aspects Regarding the Judiciary in the Protection of Human Rights in Africa', Presented at the First Summit of Constitutional, Regional and Supreme Court Justices, Mexico City, 8-9 November 2012, available at: \{www.africancourt.org/en/images/Other\%20Reports/Report_of_the_African_Court_on_Human_and_Peoples_Rights_in_the_ Protection_of_Human_Rights_in_Africa_final.pdf \}, accessed 19 March 2018, para. 20.

${ }_{108}$ Interview 9, ACtHPR administrator, Arusha, 1 December 2015.

${ }^{109}$ Interview 7, Judge of the ACtHPR, Arusha, 30 November 2015.

${ }^{110}$ Sylvain Oré, 'Opening Statement by the President: 48th Ordinary Session of the ACtHPR', Arusha, 26

February 2018, available at: \{www.african-

court.org/en/images/Speeches/EG_48th_Opening_Statement_Prez_26_March_2018.pdf\}, accessed 23 March 2018, p. 3-4.
} 
remedy poor public acceptance, stating: 'the Court has taken the unusual policy decision to strategically improve its visibility and accessibility to all relevant stakeholders by undertaking activities that inform them of its existence, its mandate and how it may be utilized'. ${ }^{111}$ 'Sensitization' visits are one such activity. Among the objectives stated for sensitization are 'raising public awareness about the Court...[and] encouraging the public to utilise the Court in settling human rights disputes' ${ }^{112}$ The Court also relies on media and technology to 'reach out to those people who are not here [in Arusha]. ${ }^{113}$ The Court has provided media training on how to cover the Court. In 2013, for instance, the Court organized a conference for the media. It "was attended by a total of 67 journalists and media practitioners from thirty (30) African countries and 10 Judges of the African Court. At the end of the two-day conference, the participants adopted conclusions on how to work to enhance the visibility of the Court in particular and promote human rights as a whole'. ${ }^{114}$ Also, the Court distributes promotional materials (e.g., posters, pamphlets, videos, etc.). ${ }^{115}$ The ACtHPR maintains a website and social media profiles (e.g., Twitter, Facebook) to have a public presence.

\section{Content of Judicial diplomacy}

The judicial diplomacy of the Court, as mentioned above, includes information about its procedural and substantive law. For example, the Court's jurisprudence and procedures

\footnotetext{
${ }^{111}$ Akuffo, 'Report of the ACtHPR on the Relevant Aspects Regarding the Judiciary in the Protection of Human Rights in Africa', para. 21.

112 ACtHPR, 'Press Release: African Court Successfully Concluse Three Day Sensitization Mission to Cape Verde'.

${ }^{113}$ Interview 10, Judge of the ACtHPR, Arusha, 3 December 2015.

${ }^{114}$ ACtHPR, 'Activity Report of the African Court for the Year 2013', para. 82.

115 These activities are supported by external funders. Interviewees revealed that the funders do not dictate what activities the ACtHPR conducts. Interview 3 and 4, GIZ representatives, Arusha, 26 November 2015; Interview 9.
} 
were presented during the moot court competition, ${ }^{116}$ by Judge Râfaa's presentation during a sensitization, ${ }^{117}$ and its YouTube video presentations. ${ }^{118}$ The Court's website also publicizes its procedures and case law. Less prominent to such informational content is praising or shaming of states for their respect of human rights.

The judicial diplomacy of the ACtHPR typically couples informational content with norm-referential narratives about its processes and outcomes. For example, the Court's website states that one of its core values is 'fair and impartial application and interpretation' of human rights law. ${ }^{119}$ The Court conveys or displays these values while practicing judicial diplomacy. ${ }^{120}$ Former president of the Court, Justice Niyungeko explained: 'the Court pledges to discharge its role as the judicial pillar of the African Union with independence, justice and fairness. ${ }^{121}$ The Court makes other norm-referential statements pertaining to its processes, like how its adherence to rules of admissibility and the exhaustion of local remedies. For example, during the moot court competition, the Court emphasized its respect for these rules. ${ }^{122}$

Similarly, the ACtHPR communicates narratives concerning its outcomes, including its respect for its mandate. One interviewee explained:

One of the key points I make when I talk with some ambassadors and some senior officials is 'No, don't look at the Court as an institution that is trying to condemn what

\footnotetext{
116 Participant observation, Remarks by Registrar Robert Eno and Justice Duncan Tambala, Arusha, 30 November 2015.

${ }^{117}$ Ben Achour Râfaa, 'La Cour Africaine des Droit de l'Homme et des Peuples', Presented at the Sensitization Visit to Tunisia, April 2017, available at: $\{$ https://en.africancourt.org/images/Speeches/La_Cour_Africaine_des_droits_de_lHomme-Judge_Raafa.pdf\}, accessed 17 June 2020; as video, available at: https://www.youtube.com/watch?v=j56Zg06jyYw\&t=17s \}, accessed 17 June 2020. 118 ACtHPR, 'African Court on Human and Peoples' Rights on Freedom of Expression', 16 October 2016, available at: $\{$ https://www.youtube.com/watch?v=eaC5_QwdKv4 \}, accessed 17 June 2020; ACtHPR, 'Basic facts - African Court on Human and Peoples' Rights', 19 september 2019, available at: \{https://www.youtube.com/watch?v=xcTjtZHyIU8\}, accessed 17 June 2020.

${ }^{119}$ See $\{$ https://en.african-court.org/index.php/about-us/mandate-vision-mission-values $\}$ accessed 16 June 2020.

${ }^{120}$ E.g., participant observation; Râfaa, 'La Cour Africaine des Droit de l'Homme et des Peuples' (YouTube video).

${ }^{121}$ Gerard Niyungeko, 'Presentation during the 5th Ordinary Session of the Second Parliament of the Pan African Parliament', 6 October 2011, Midrand, South Africa.

${ }^{122}$ Participant observation.
} 
you do, just look at it as an institution trying to bring you in line with the Charter which you have voluntarily signed.' So when we try to tell them like that, there is some understanding. We also try to tell them that we are not replacing your appellate courts. We are not interfering with their sovereignty, we are only there to help your appellate court do what it should do. ${ }^{123}$

As this judge explained, the message to states is that the Court works with them to realize human rights. Court representatives related a similar narrative regarding the Court's respect for state sovereignty at the 2015 moot court competition. ${ }^{124}$

The Court's judicial diplomacy signals its commitment to its founding purpose: the protection of human rights and effective justice for these rights. At the Third Continental Judicial Dialogue, President Oré explained: 'to render a more effective justice in Africa is no longer an option. It is imperative!' 125 The Court reveals this commitment to human rights through its promotion of other human rights institutions. When addressing audiences where the Court does not have jurisdiction, one interviewee explained that efforts are made to point to other institutional opportunities for the protection of human rights, such as the ACmHPR or the court of ECOWAS. ${ }^{126}$ The Court also highlights its complementarity with the ACmHPR. ${ }^{127}$ The prominence of parallel human rights institutions in the Court's judicial diplomacy signals its broad commitment to human rights and its overall political purpose.

The Court also refers to its promotion of African values and goals. In another statement, Oré expressed how human rights reflect a common African goal: 'it is our

\footnotetext{
${ }^{123}$ Interview 6, Judge of the ACtHPR, Arusha, 28 November 2015.

${ }^{124}$ Participant observation.

${ }^{125}$ Sylvain Oré, 'Speech by His Excellency Sylvain Ore, President of the ACtHPR. The Opening Ceremony of the Third Contintenal Judicial Dialogue', Arusha, 9 November 2017, available at: \{www.africancourt.org/en/images/Speeches/Opening_Prez_3rd_JD_2017.pdf \}, accessed 23 March 2018.

${ }^{126}$ Interview 6.

${ }^{127}$ Participant observation.
} 
struggle, our common responsibility for an Africa which places human rights at the heart of the African Union reforms and as the key to socio-economic and human development'. ${ }^{128}$ On another occasion, Oré asserted how the Court is 'neither a Court for the States nor a Court of the Judges, but rather a Court for all African citizens'. ${ }^{129}$ He claimed that 'to build a more worthy, more humane and more prosperous Africa' is a 'common struggle'. ${ }^{130}$

To summarize, the ACtHPR's judicial diplomacy targets public officials as well as substate and nonstate actors, which can be associated with the mobilization of compliance constituencies and socialization. The ACtHPR's judicial diplomacy provides information about the law when addressing these audiences, as would be expected of efforts to mobilize compliance constituencies. Less prominent are validity claims about the law, such as shaming and praising of norm (un)acceptance, to socialize public officials. It also targets the public to a significant degree, alongside audiences where the Court has noted deficits of support. When addressing these audiences, the Court's judicial diplomacy is embedded with narratives about its processes and outcomes, including its adherence to proper rules, its commitment to its mandate and its promotion of common African values and goals. Stated differently, the ACtHPR's judicial diplomacy takes a public-oriented and people-centred approach.

\section{Judicial diplomacy and the Caribbean Court of Justice}

The CCJ became operational in 2005 and was established by member states of the Caribbean Community (CARICOM) in 2001 upon the adoption of the Agreement Establishing the Caribbean Court of Justice (CCJ Agreement). CARICOM is a regional integration organization of fifteen Caribbean states, most of which are former British

\footnotetext{
128 Oré, 'Opening Statement by the President: 48th Ordinary Session of the ACtHPR', p. 3.

${ }^{129}$ Business Ghana. 2016. "African Court Rejuvenated for the Next 10 Years," November 23. Available at: http://www.businessghana.com/site/news/business/138199/African-Court-rejuvenated-for-the-next-10-yrs (Accessed March 23, 2018).

${ }^{130}$ Ibid.
} 
colonies. The CCJ has dual jurisdiction: appellate and original. In states that have accepted the appellate jurisdiction, the CCJ replaces the UK's Judicial Committee of the Privy Council as the national court of last resort. ${ }^{131}$ The CCJ's original jurisdiction involves the interpretation and application of CARICOM law, such as the organization's founding treaties - the Treaty of Chaguaramas (1973) and the 2001 Revised Treaty of Chaguaramas (RTC). The Court's original jurisdiction is available to individuals or entities. Member states can file cases against other member states and organs of CARICOM, and national courts may refer questions of community law to the CCJ.

\section{Targets of Judicial Diplomacy}

Since its beginning, the CCJ has conducted judicial diplomacy, targeting a variety of actors. The CCJ reaches out to public officials. The President of the CCJ pays 'courtesy calls' to government officials. For example, in 2015-2016, the Court's president visited with government officials in Antigua, Guyana, St. Lucia, and St Vincent and the Grenadines. ${ }^{132}$ The CCJ views these courtesy calls as 'essential to ensure the continued awareness of the challenges facing regional judiciaries and include giving guidance on possible solutions' ${ }^{133}$

CCJ judges are frequently at events, representing the Court, with members of governments. ${ }^{134}$

The CCJ's judicial diplomacy also targets civil society and legal professionals through seminars, conferences, and training workshops. For example, the CCJ hosted, in partnership with the Guyanese judiciary, a judicial training workshop. ${ }^{135}$ A large part of the Court's judicial diplomacy that targets legal professionals is conducted under the auspices of Court's

\footnotetext{
${ }^{131}$ Only four states (Barbados, Belize, Dominica, and Guyana) are subject to the appellate jurisdiction. 132 CCJ, 'Annual Report: 2016-2017' (Port of Spain: CCJ, 2017), available at: \{www.ccj.org/publications/annual-reports\}, accessed 1 April 2019, p. 40.

${ }^{133}$ Ibid.

${ }^{134}$ Interview 22, Judge of CCJ, Port of Spain, 4 April 2016.

135 CCJ, 'Media Release No. 4: 2014' (Port of Spain: CCJ, 2014), available at: \{https://ccj.org/wpcontent/uploads/2014/02/MEDIA-RELEASE-4-2014.pdf \}, accessed 11 February 2020.
} 
'educational arm'. This includes an entity established and managed by the Court called the CCJ Academy for Law, previously known as the Caribbean Academy for Law and Court Administration. The CCJ Academy aims to provide 'informative and innovative perspectives on the rules and the roles of law' and 'a platform for examining court administration and encouraging best practices in the judicial administration of justice'. ${ }^{136}$ It organizes seminars, workshops, exchanges, special lectures, and a biennial conference. ${ }^{137}$ For law students, the Court runs an annual international law moot court. The CCJ hosted its $11^{\text {th }}$ moot court competition in 2019. ${ }^{138}$ Additionally, the Court's judges attend and speak at a wide range of events throughout the region and beyond. Between 2005 and 2019, the Court recorded 145 such presentations. Among others, judges gave speeches to law schools, bar associations, and professional associations for judges.

While the CCJ's judicial diplomacy targets actors who are relevant for mobilizing compliance constituencies and socialization, a significant portion of it focuses on the public - where a highly relevant deficit of support exists. Among the CCJ's key challenges is accession to the Court's appellate jurisdiction. As Justice Byron explained, this is 'the most compelling matter for the Court'. ${ }^{139}$ States' acceptance of the appellate jurisdiction requires constitutional reforms in member states through popular referendum. The reluctance across the region to accept the CCJ's appellate jurisdiction is perhaps attributable to poor knowledge about the $\mathrm{CCJ}^{140}$ and societal perceptions that the Court lacks independence, ${ }^{141}$ among other

\footnotetext{
${ }^{136}$ CCJ Academy, 'Overview of the CCJ Academy for Law', www.ccjacademy.org/about-ccj-afl/overview\}, accessed 1 April 2019.

137 Ibid.

${ }^{138}$ CCJ, '11th Annual Caribbean Court of Justice International Law Moot Court' (Port of Spain: CCJ, 2019), available at: \{www.ccj.org/events/11thannuallawmoot $\}$, accessed 1 April 2019.

${ }^{139}$ Dennis Byron, 'Remarks at the International Law Moot 2018 Award Ceremony', Port of Spain, 9 March 2018, available at: \{www.ccj.org/publications/papers-speeches\}, accessed 1 April 2019, p. 8.

${ }^{140}$ Interview 17, Judge of CCJ, Port of Spain, 4 April 2016.

${ }^{141}$ Interview 22.
} 
things. Moreover, the Court's flow of cases in its original jurisdiction is 'sluggish'. ${ }^{142}$ The original jurisdiction relies largely on stakeholders petitioning the Court.

The CCJ recognizes there are significant gaps in public support. In fact, one of the overarching themes of the Court's current strategic plan is public 'trust and confidence'. ${ }^{143}$ Similarly, 'attaining and preserving public trust and confidence' was a theme of the Court's previous strategic plans. ${ }^{144}$ Several interviewees expressed concern for the CCJ's public image and pointed to initiatives the CCJ has taken to address its public reputation. The CCJ's registry has a unit dedicated to 'public education'. At its beginning, the CCJ initiated 'a public outreach programme, through which it interfaces directly with the Caribbean public, either by inviting groups into the Court for contact sessions, or by taking its message 'on the road' as it were, into the very heart of constituent communities'. ${ }^{145}$ Taking the message 'on the road', in part, means literally taking the Court on the road. On occasion the CCJ sits in locations other than at its headquarters in Trinidad. For example, it held sittings in Belize in 2015, Guyana in 2014, Jamaica in 2013, and Barbados in 2012, among others. ${ }^{146}$ More recently, the CCJ sat in St. Vincent \& the Grenadines. President Justice Saunders $(2018,1)$ explained that this sitting was ' ... an opportunity for the people of St. Vincent and the Grenadines to see and meet with the judges of the CCJ.' ${ }^{147}$

\footnotetext{
142 CCJ, 'Annual Report 2017-2018' (Port of Spain: CCJ, 2018), available at: \{www.ccj.org/publications/annual-reports\}, accessed 1 April 2019, p. 3.

${ }^{143}$ CCJ, 'Unlocking Potential: Strengthening Caribbean Jurisprudence, Strategic Plan 2019-2024' (Port of Spain: CCJ, 2019), available at \{www.ccj.org/publications/ccj-strategic-plan\}, accessed 1 April 2019, p. 14. ${ }^{144}$ CCJ, 'Responsive, Innovative, Inspirational: The Caribbean Court of Justice Strategic Plan, 2013-2017' (Port of Spain: CCJ, 2012), available at \{www.ccj.org/publications/ccj-strategic-plan\}, accessed 1 April 2019, p. 11. 145 CCJ, 'Annual Report: 2005-2006' (Port of Spain: CCJ, 2006), available at: \{www.ccj.org/publications/annual-reports\}, accessed 1 April 2019, p. 22.

${ }^{146}$ CCJ, 'Media Release No. 15: 2015' (Port of Spain: CCJ, 2015), available at: \{https://ccj.org/wpcontent/uploads/2011/11/MEDIA-RELEASE-15-2015.pdf \}, accessed 1 April 2019.

${ }^{147}$ Adrian Saunders, 'Speech delivered at Special Sitting in St. Vincent \& the Grenadines of the Caribbean Court of Justice', St. Vincent \& the Grenadines, 20 July 2018, available at: \{www.ccj.org/publications/papersspeeches $\}$, accessed 1 April 2019, p.1
} 
The CCJ has hosted public education events, including one in Belize in 2008 and Grenada in 2011. ${ }^{148}$ The events in Grenada included 'town hall meetings, in which CCJ officials went into the communities to interface with the people and provide them with information about the Court. The contingent also made media appearances on radio and television stations throughout Grenada, and hosted a media conferences'. ${ }^{149}$ More recently, the CCJ participated in consultations in Antigua prior to a national referendum on the CCJ's appellate jurisdiction. ${ }^{150}$

Further illustration of how judicial diplomacy targets the public is a series called 'Did you know'. This series provided easy to know information on the role, functions and work of the CCJ, which was disseminated as newspaper advertisements in all CARICOM states and one-minute television ads throughout the region. ${ }^{151}$ The Court communicates to a broader public through social media and website where it streams hearings. As this description shows, in line with the expectations for legitimation, the CCJ's judicial diplomacy targets the public and audiences where deficits in support occur.

\section{Content of Judicial diplomacy}

Aspects of judicial diplomacy disseminates information about the substantive and procedural provisions of Caribbean law. For instance, Justice Byron explained that the CCJ's moot competition encourages 'aspiring attorneys to become familiar with the Revised Treaty of Chaguaramas and other areas of international law... it serves as a medium through which law students in the Caribbean can be exposed to integral principles of the Treaty and the

\footnotetext{
148 CCJ, 'Media Release No. 1: 2008' (Port of Spain: CCJ, 2008), available at: \{https://ccj.org/wpcontent/uploads/2012/01/PRESS-RELEASE-01-2008.pdf \}, accessed 1 April 2019; CCJ, 'Media Release No. 6: 2011' (Port of Spain: CCJ, 2011), available at: \{https://ccj.org/wp-content/uploads/2012/01/MEDIARELEASE-06-2011.pdf\}, accessed 1 April 2019.

${ }^{149}$ CCJ, 'Annual Report: 2010-2011' (Port of Spain: CCJ, 2011), available at: \{https://www.ccj.org/publications/annual-reports/\}, accessed 1 April 2019, p. 28.

${ }^{150}$ CCJ, 'Media Release No. 24: 2015' (Port of Spain: CCJ, 2015), available at: \{https://ccj.org/wpcontent/uploads/2011/11/MEDIA-RELEASE-24-2015.pdf $\}$, accessed 1 April 2019.

${ }^{151}$ CCJ, 'Annual Report: 2010-2011', p. 25.
} 
regional integration movement'. ${ }^{152}$ The CCJ's moot court is a unique opportunity for students to engage with the law of CARICOM. ${ }^{153}$ An examination of the speeches delivered by CCJ's judges reveals that they convey information about the procedural and substantive content of the law. Moreover, the Court's annual reports and press releases provide summaries of its jurisprudence and the Court's website hosts all of its judgments. The Court's judicial diplomacy does not tend to make validity claims about the substantive law.

The CCJ's judicial diplomacy couples information on the procedural and substantive law with narratives about the Court. It asserts its respect for proper procedures and fair and impartial adjudication. As President Saunders stated: 'The people of the region can truly be proud of this court, of its independence and the integrity of its court processes'. ${ }^{154}$

The CCJ's judicial diplomacy highlights outcome related narratives, such as its commitment to its mandate. For example, prior to the Grenadian referendum on the CCJ's appellate jurisdiction in 2014, the Court's released a statement, saying said: 'the Court assures the people of the Caribbean Community in general and people of Grenada in particular that it remains committed to the discharge of the mandate given it in its constituent treaties... [and] to play a determinative role in the further development of Caribbean jurisprudence through the judicial process'. ${ }^{155}$ Similarly, at the special sitting in St. Vincent and the Grenadines, President Saunders proclaimed: 'The CCJ has no desire to be involved in the political decision making of any country'. ${ }^{156}$

\footnotetext{
152 Dennis Byron, 'Opening Remarks at the 6th Annual CCJ International Law Moot Competition', Port of Spain, 14 March 2014, available at: \{www.ccj.org/publications/papers-speeches\}, accessed 1 April 2019 , p. 1. ${ }^{153}$ Interview 19, Judge of CCJ, Port of Spain, 24 March 2016. 
A large amount of the CCJ's judicial diplomacy portrays the Court's commitment to justice and the rule of law. For example, Justice Hayton in a public speech stated: 'We judges have devoted our lives...to developing the law so that citizens can have fulfilling lives in a democratic society where the rule of law prevails' ${ }^{157}$ As the Court states, 'the CCJ remains an advocate for and provides support to improvements within the region's judicial systems' ${ }^{158}$ Specifically, the CCJ's judicial diplomacy focuses on educating and assisting judiciaries throughout the region to improve the rule of law. For example, the CCJ Academy is intended for this purpose. Similarly, with the Canadian government, the CCJ has a project on improving the justice sector in the region. ${ }^{159}$

The CCJ's judicial diplomacy does not focus only on CARICOM law, but justice and the rule of law generally. One interviewee explained, the CCJ is 'helping the member states improve their administration of justice capacity in the individual countries. And to that extent is also serving to imprint into the consciousness of the public of the Caribbean the legitimacy of the Court'. ${ }^{160}$ These efforts signal the CCJ's commitment to its political purpose, including the protection of the rule of law within the region.

Through its judicial diplomacy, the CCJ also communicates its respect for community values. For instance, President Saunders told stakeholders: 'The CCJ is my court, your court, the region's court'. ${ }^{161}$ Other judges present the CCJ as a reflection of the Caribbean people and its values. When speaking to law students at the 2018 moot court competition, then President Byron stated: 'Culminated in the existence of this Court, your Court, are the

\footnotetext{
${ }^{157}$ David Hayton, 'Speech delivered at Special Sitting in St. Vincent \& the Grenadines of the CCJ', St. Vincent $\&$ the Grenadines, 20 July 2018, available at: \{www.ccj.org/publications/papers-speeches\}, accessed 1 April 2019, p. 5.

${ }^{158}$ CCJ, 'Annual Report: 2016-2017' (Port of Spain: CCJ, 2017), available at:

\{www.ccj.org/publications/annual-reports\}, accessed 1 April 2019, p. 41.

159 Interview 19.

${ }^{160}$ Interview 25, Representative of bar association, Port of Spain, 6 April 2016.

${ }^{161}$ Adrian Saunders, 'The Role of the Caribbean Court of Justice in the Private Sector: Guyana Manufacturing and Services Association Ltd.', Guyana, 2 August 2018, available at: \{www.ccj.org/publications/papersspeeches\}, accessed 1 April 2019, p. 20.
} 
aspirations of Caribbean peoples. And it is a hope that the Caribbean Court of Justice by its existences epitomises. The CCJ is currently poised to contribute to positive change in the social order of our Caribbean societies by delivering justice which is accessible, efficient and reflective of our values and mores.' 162

The CCJ portrays itself as a reflection of the Caribbean, using 'Your People. Your Region. Your Court' as a motto on its website. The sentiment of this motto is woven throughout representations of the Court made in various arenas. For example, while presenting to a regional bar association, Justice Anderson argued: 'The Caribbean Court of Justice plays an important symbolic role to us as Caribbean people because, in its appellate jurisdiction, it represents the culmination of our journey towards independence, the severance of our ties from our former colonial masters, and a conscious decision to chart our own jurisprudential course'. ${ }^{163}$ Similarly, then President Byron told an audience at the University of West Indies '...the CCJ affords the opportunity, by its judgments, more closely to align the trajectory of Caribbean jurisprudence with the mores, values, goals, needs and aspirations of Caribbean people; that although the CCJ will not create a Caribbean jurisprudence, it will certainly be better positioned to bring that jurisprudence closer to the people of the Caribbean since the final appellate court will now comprise Caribbean nationals and judges who reside in the Caribbean'. ${ }^{164}$

In sum, much like the ACtHPR, the CCJ's judicial diplomacy targets public officials and substate and nonstate actors, which we would expect for mobilizing compliance constituencies and socialization. When targeting these actors, the content of the CCJ's judicial diplomacy does include legal information, and to a lesser extent persuasive

\footnotetext{
162 Dennis Byron, 'Remarks at the International Law Moot 2018 Award Ceremony', p. 5.

${ }^{163}$ Winston Anderson, 'Free Movement within CARICOM: Deconstructing Myrie v. Barbados', Paper presented at OECS Bar Association Meeting, St. Georges, Grenada, 7 December 2013, available at: \{www.ccj.org/publications/papers-speeches\}, accessed 1 April 2019, p. 2-3.

164 Dennis Byron, 'Eminent Speakers Lecture of the UWI Law Society, Faculty of Law, Barbados, 9 November 2011, available at: \{www.ccj.org/publications/papers-speeches\}, accessed 1 April 2019, p. 3.
} 
arguments about the law. A significant portion of its judicial diplomacy, however, targets the public, which tends to include norm-referential narratives about the Court's processes and outcomes.

\section{Conclusion}

This analysis explored how and why ICs use judicial diplomacy and reveals three main findings. First, the ACtHPR and CCJ's judicial diplomacy is public-oriented, which is uniquely expected of legitimation. These courts express concern for their public image and have instrumentally developed strategies to address the public's views. Both courts also orient their judicial diplomacy toward interested stakeholders, such as public officials, legal professionals and civil society, especially where the courts believe they has legitimacy deficits. For example, the ACtHPR's diplomacy is oriented toward public officials in order to encourage more states to ratify its protocol, while the CCJ focuses on gaining widespread accept of its appellate jurisdiction.

Second, the ACtHPR's and CCJ's judicial diplomacy, especially when targeting the public and audiences where support deficits exist, communicates norm-referential narratives about the courts themselves. Their messaging underscores how their processes conform to key values. They frequently signal their adherence to rules and respect for fair, impartial and independent adjudication. In addition, their judicial diplomacy addresses outcomes, such as commitment to their political purpose and mandate, and is people-centred. The ACtHPR's rhetoric emphasizes its commitment to human rights, while the $\mathrm{CCJ}$ affirms its commitment to the rule of law and regional integration. Both courts refer to how they represent the communities they serve and reflects common goals or struggles of their respective people. 
Third, I observe information sharing that is directed toward compliance constituencies. Both the ACtHPR and CCJ target actors who can facilitate compliance, especially national judges, lawyers and NGOs, and they dissemination information on how to access the courts and their jurisprudence. This confirms that judicial diplomacy can be employed to mobilize compliance constituencies. Information sharing is, however, consistently coupled with public-oriented and people-centred narratives observed in the ACtHPR's and CCJ's judicial diplomacy. I find less evidence of persuasive argumentation about the law that is intended for public officials. These findings suggest that a full account of judicial diplomacy requires recognition of the role that legitimation plays and its complementarities with the mobilization of compliance constituencies.

Do these findings relate to the broader universe of ICs and what are the scope conditions of judicial diplomacy for legitimation purposes? The analysis indicates plausible conditions to the argument. As the normative yardsticks of legitimacy have evolved, the public-oriented and people-centred characteristics of judicial diplomacy is probably a more recent phenomenon and less relevant historically. In other words, the target audiences and primary content will most likely vary according to the normative yardsticks for legitimacy of the day. This may explain why we observe older courts, like the CJEU and ECtHR, only recently developing public-oriented and people-centred judicial diplomacy. Future research could bring greater clarity to whether judicial diplomacy has evolved over time.

As for generalisability, this analysis suggests that legitimation is crucial to understanding the judicial diplomacy of a wide array of ICs, irrespective of institutional design. As the two cases show, judicial diplomacy for legitimation purposes applies to ICs with distinct institutional designs. The ACtHPR is a human rights court while the CCJ's jurisdiction is a regional integration court. The two courts also differ in regard to the selection of judges and the terms of their appointment, funding, access and admissibility rules, and 
competing jurisdictions. The ACtHPR's and CCJ's judicial diplomacy reflect legitimation as a key motivation, despite these significant differences. These cases however leave open the question of whether ICs with only state-to-state disputes will feature public-oriented and people-centred diplomacy (however, today this comprises a small minority of ICs). While the cases analysed here do help to clarify the scope and generalizability of the argument, future research is necessary to determine the full range of factors that inform judicial diplomacy as legitimation and its complementarities with the mobilization of compliance constituencies

This article has implications for research on ICs. It argues that when viewed as diplomacy ICs' nonjudicial activities take on broader meaning. Defined as the processes by which international courts represent and claim their authority in their interfacing with external actors, judicial diplomacy casts nonjudicial activities as strategically planned political behaviours. These behaviours are not merely coincidental to the existence and operating of ICs. Rather, as these behaviours reflect strategic efforts to boost legitimacy, they are part and parcel to understanding the performance and authority of international courts. ${ }^{165}$

This article also has implications for literature on the legitimation of international institutions. It suggests that legitimation extends to international courts, which previously received little attention by this literature, and it complements previous findings that today's international institutions rely on public-oriented, people-centred legitimation. ${ }^{166}$ However, in contrast to this literature, the findings here show that legitimation strategies can develop in the infancy of an institution, and need not be tied to specific crises or political pressures. In other words, legitimation may be linked to the process of institutional establishment and development. Moreover, it suggests future research could bring further light to the synergies between legitimation and diplomacy.

\footnotetext{
${ }^{165}$ Alter et al., International Court Authority; Squatrito et al., The Performance of International Courts and Tribunals.

${ }^{166}$ Dingwerth et al., International Organizations under Pressure.
} 